\title{
EFFECT OF GIBBERELLIC ACID ON GROWTH, TUBER YIELD AND QUALITY IN POTATOES (Solanum tuberosum L.)
}

\author{
Sevgi CALISKAN ${ }^{\prime}$, Mohammad Samim HASHEMII, Mustafa AKKAMIS ${ }^{l}$, \\ Ramazan Ilhan AYTEKIN ${ }^{1}$, Mehmet BEDIR ${ }^{2}$ \\ ${ }^{I}$ Nigde Omer Halisdemir University, Faculty of Agricultural Sciences and Technologies, Department of \\ Plant Production and Technologies, Nigde, TURKEY \\ ${ }^{2}$ Sivas University of Science and Technology, Faculty of Agricultural Sciences and Technologies, \\ Department of Plant Production and Technologies, Sivas, TURKEY \\ * Corresponding author: sevcaliskan@gmail.com
}

Received: 06.05.2021

\begin{abstract}
The purpose of this study was to determine the effects of different doses of gibberellic acid $\left(G_{3} A_{3}\right.$ on growth, tuber yield and some tuber quality traits of potato. The experiment was arranged in a split-plot design with three replicates, cultivars Marabel, Alegria and Agria were arranged in the main plots, and GA3 doses $(0,25$, 50 and $100 \mathrm{mg} \mathrm{GA}_{3} \mathrm{~L}^{-1}$ ) in the sub-plots. Gibberellic acid was applied to leaves by spraying on the $50^{\text {th }}$ day after planting (during flowering). The effects of $\mathrm{GA}_{3}$ applications on tuber yield of potato cultivars were varied. GA3 applications resulted in significant decrease on chlorophyll content (SPAD), tuber dry matter and chips quality of potato. But it caused significant increase on number of tubers and tuber yield plant ${ }^{-1}$. In 2019 and 2020 years, the highest tuber yield was obtained from Alegria cultivar (62.78 and $50.55 \mathrm{t} \mathrm{ha}^{-1}$ respectively). Total tuber yield values increased from $52.08 \mathrm{t} / \mathrm{ha}$ to $65.14 \mathrm{t} \mathrm{ha}^{-1}$ in 2019 and from $42.12 \mathrm{t} \mathrm{ha}^{-1}$ to $53.94 \mathrm{t} \mathrm{ha}^{-1}$ in 2020 with increasing to $100 \mathrm{mg} \mathrm{GA}_{3} \mathrm{~L}^{-1}$ from $0 \mathrm{mgL}^{-1}$. Overall, increasing doses of GA3 resulted in a reduction in tuber dry matter and starch ratio. The GA3 applications caused deformations in tuber shape, the deformations increased with increasing GA3 doses.
\end{abstract}

Keywords: Dry matter content, gibberellic acid, Solanum tuberosum, SPAD, tuber yield

\section{INTRODUCTION}

Potato tubers have a domestic consumption (a few examples are finger, chips, flour, puree, starch, instant soup, etc.) and are also used in the production of alcohol and its derivatives. With industrialization, easy and prepackaged consumption has a great effect on this usage. Starch is an important industrial raw material that is involved in the production of food, sugar, textiles, paper, glue, alcohol, and spirits, and potato tubers are used directly or as factory residues and animal feed. Tubers and dried stems are also used in animal nutrition (Caliskan et al., 2010).

Organic molecules that can affect the growth, development, and other physiological activity in the plant positively or negatively, can be transported to other parts of the plant and can show their activity in these organs are called hormones (phytohormone-plant growth regulators). Gibberellins (17\%), one of the Natural Plant Growth Regulators, are among the most widely used plant hormones in the world (Kumlay and Eryigit, 2011). In plants gibberellins are abundant in buds, embryos, roots, young leaves, flowers, fruits, and cambiums. Among the Gibberellins, $\mathrm{GA}_{3}$ (Gibberellic acid) is the most widely used in agriculture. Gibberellins are known to be highly effective in increasing cell growth, breaking seed and bud dormancy, eliminating stunting, eliminating chilling needs, promoting germination, increasing longitudinal growth and branching (Algul et al., 2016).

Tuber formation in potatoes is a complex developmental process in which environmental, biochemical, and genetic factors play a role (Kolomiets et al., 2001). The initiation of stolon formation and the growth of stolons in potatoes is the beginning of tuber formation. After the longitudinal extension of the stolons stops, tuber formation begins and tuber growth continues (Sarkar, 2008). The initiation of stolon formation is associated with the accumulation of carbohydrates in the stems under the soil. However, the levels of carbohydrate accumulation required for the initiation of stolon is lower than that the initiation of tuber formation. Stolon formation is also associated with gibberellin levels in the plant (Abdala et al., 2000). External application of gibberellins promotes stolon growth (Vreugdenhil and Helder, 1992) but prevents tuber formation (Puzina, 2004). Tuber growth and development depend on 
sufficient green component to provide adequate water and nutrients and produce the necessary assimilates.

Gibberellic acid promotes the number of stolon that enable tuber formation and it also ensures an increase in number of leaves that will help to provide assimilates required for tuber growth. The economic value of a potato is determined not only by the total tuber yield but also by the tuber size distribution and tuber dry matter content included in tuber quality property. Therefore, studies have been conducted to improve tuber quality, including plant growth regulators (Sarkar, 2008). It has been demonstrated that Gibberellins (GA) stimulate stem growth and stolon growth (Vreugdenhil and Helder, 1992), inhibit or delay tuber initiation (Sarkar, 2008), increase the number of tubers (Mikitzel, 1993; Njoqu et al., 2015), inhibit starch synthesis (Barani et al., 2013), reduce the dry matter and starch ratio, and increase the protein ratio (Javanmardi and Rasuli, 2017).

The purpose of the study was to determine the effects of different concentrations of gibberellic acid on plant growth, tuber formation, tuber yield, and some quality characteristics of some potato genotypes.

\section{MATERIALS AND METHODS}

Field experiment was conducted in the Research and Application Area of Nigde Omer Halisdemir University Faculty of Agricultural Sciences and Technologies, Department of Plant Production and Technologies in 2019 and 2020.

Soil samples were collected from experimental area at 0-30 cm depth before basal fertilizer application to test initial soil characteristics, and soil test results are presented in Table 1. The soil has a clay-loam structure, alkaline character, and a little organic matter content, and soils that are too calcareous have a salt-free character. The total nitrogen content is sufficient, the phosphorus $\left(\mathrm{P}_{2} \mathrm{O}_{5}\right)$ content is low and the potassium $\left(\mathrm{K}_{2} \mathrm{O}\right)$ content is high. The soil in which the study was conducted is sufficient in terms of iron $(\mathrm{Fe})$ and copper $(\mathrm{Cu})$ content, low in manganese $(\mathrm{Mn})$ content, very high in magnesium $(\mathrm{Mg})$ content, and high in calcium $(\mathrm{Ca})$ content. The province of Nigde has a continental climate with hot and dry summers and cold and snowy winters. The daily climatic data were obtained from the General Directorate of Nigde Meteorology Services. The mean values of the climatic date are given in Table 2.

Table 1. Some physical and chemical characteristics of the $0-30 \mathrm{~cm}$ soil layer of the experimental site

\begin{tabular}{lcc}
\hline Properties & Year 2019 & Year 2020 \\
\hline Texture & Silt Clay & Silt Clay \\
pH & 8.09 & 7.95 \\
Electrical conductivity $\left(\mu \mathrm{S} \mathrm{cm}^{-1}\right)$ & 0.027 & 0.010 \\
$\mathrm{CaCO}\left(\mathrm{g} \mathrm{kg}^{-1}\right)$ & 21.16 & 21.80 \\
Organic matter $\left(\mathrm{g} \mathrm{kg}^{-1}\right)$ & 1.91 & 3.15 \\
Total N $\left(\mathrm{g} \mathrm{kg}^{-1}\right)$ & 0.142 & 0.138 \\
Available P $\mathrm{O}_{5}\left(\mathrm{~kg} \mathrm{da}^{-1}\right)$ & 3.16 & 10.85 \\
$\mathrm{Available} \mathrm{K}\left(\mathrm{kg} \mathrm{da}^{-1}\right)$ & 159.19 & 201.19 \\
$\mathrm{Fe}\left(\mathrm{mg} \mathrm{kg}^{-1}\right)$ & 5.75 & 3.25 \\
$\mathrm{Cu}\left(\mathrm{mg} \mathrm{kg}^{-1}\right)$ & 1.36 & 1.21 \\
$\mathrm{Mn}\left(\mathrm{mg} \mathrm{kg}^{-1}\right)$ & 4.86 & 10.35 \\
$\mathrm{Zn}\left(\mathrm{mg} \mathrm{kg}^{-1}\right)$ & 1.53 & 2.15 \\
$\mathrm{Mg}\left(\mathrm{mg} \mathrm{kg}^{-1}\right)$ & 403.2 & 582.1 \\
$\mathrm{Ca}\left(\mathrm{mg} \mathrm{kg}^{-1}\right)$ & 5688 & 5572 \\
\hline
\end{tabular}

$\mathrm{pH}$ and Electrical conductivity were determined in saturation extracts.

${ }^{\mathrm{b}} \mathrm{N}$ content was determined with Khjeldahl method.

${ }^{\mathrm{c}} \mathrm{Fe}, \mathrm{Cu}, \mathrm{Zn}, \mathrm{Mg}, \mathrm{Ca}$ and $\mathrm{Mn}$ contents were determined with DTPA extraction method.

Three different potato cultivars; Marabel early, with ellipse tuber shape, yellow skin color; Alegria mid-early, with ellipse tuber shape, bright yellow skin color and Agria mid-late, with long ellipse tuber shape, yellow skin color were used as plant material. The experimental design was a split plot arrangement of randomized complete block with three replications. Main plots consisted of three cultivars. Sub-plot treatments had four $\mathrm{GA}_{3}$ doses $\left(0,25,50\right.$ and $\left.100 \mathrm{mg} \mathrm{GA}_{3} \mathrm{~L}^{-1}\right)$. Each plot consisted of 4 rows of 5.1 meters length and spacing between on the row was $70 \times 30 \mathrm{~cm}$. Seed tubers were planted by machine in a depth of $15-18 \mathrm{~cm}$ on 19 May 2019 and 20 May 2020. Four levels of $\mathrm{GA}_{3}(0,25,50$ and $100 \mathrm{mg} \mathrm{GA}_{3} \mathrm{~L}^{-1}$ ) were sprayed on the foliage of the plants using an atomizer at $50^{\text {th }}$ days after planting. Control plots were treated with distilled water at the same application time. Approximately 20 days after planting, emergence of plants was visible on the soil surface and emergence times differed according to the cultivars. For weed control, Metribuzin was applied to soil at the rate of $800 \mathrm{ml} \mathrm{ha}^{-1}$ in the field before emergence and the plots were maintained as weed-free by hand weeding during growing period. Each plot was applied with a basal dose of phosphorus $(\mathrm{P})$ and potash $(\mathrm{K})$ fertilizers at the rate of $110 \mathrm{~kg} \mathrm{P}+110 \mathrm{~kg}$ $\mathrm{K} \mathrm{ha}^{-1}$ at the planting. Nitrogen was applied at the rate of $250 \mathrm{~kg} \mathrm{ha}^{-1}$ in split form (half at planting and half at tuber formation period) as a side dress in the form of urea. After planting, a sprinkler irrigation system was installed in the experimental area and regular irrigation was done at intervals of 5-7 days. On the $60^{\text {th }}$ day after the emergence 
of the shoots to the soil surface, leaf chlorophyll contents were determined through Minolta SPAD 502 Chlorophyll Meter in each plot. Potatoes were harvested on 01 October 2019 and on 15 September 2020. Ten plants were harvested at maturity from the first and fourth rows of each plot for measuring plant height $(\mathrm{cm})$, number of stems plant ${ }^{-1}$, number of tubers plant ${ }^{-1}$, and tuber yield plant $^{-1}$. After harvesting, the number and weight of tubers over $25 \mathrm{~mm}$ and tubers smaller than $25 \mathrm{~mm}$ or no use- value were counted and weighed separately. After the harvest, approximately $2 \mathrm{~kg}$ of potato samples were taken from each plot and their specific gravity was measured with the help of PW-2050 Digital Potato Hydrometer and dry matter ratios were calculated as based on specific gravity. Tubers obtained from all plants in the harvest area were weighed and the tuber yields of the plot for each application were determined.

Table 2. Monthly rainfall, temperature and relative humidity during the growing period of 2019 and 2020

\begin{tabular}{|c|c|c|c|c|c|c|c|c|c|}
\hline \multirow{2}{*}{ Months } & \multicolumn{3}{|c|}{ Mean Temperature $\left({ }^{\circ} \mathrm{C}\right)$} & \multicolumn{2}{|c|}{ Rainfall (mm) } & \multicolumn{4}{|c|}{ Relative humidity (\%) } \\
\hline & $\overline{\text { Long-term }}$ & 2019 & 2020 & Long-term & 2019 & 2020 & Long-term & 2019 & 2020 \\
\hline May & 15.1 & 17.6 & 16.0 & 48.7 & 26.2 & 21.2 & 52.7 & 46.7 & 52.3 \\
\hline June & 19.1 & 21.3 & 19.8 & 27.9 & 43.4 & 26.7 & 51.3 & 52.3 & 47.9 \\
\hline July & 22.4 & 22.2 & 24.6 & 5.2 & 8.3 & 0 & 39.5 & 43.9 & 40.5 \\
\hline August & 22.3 & 22.6 & 22.5 & 6.6 & 6.0 & 0 & 40.2 & 47.0 & 35.0 \\
\hline September & 18.0 & 18.2 & 22.0 & 10.5 & 6.0 & 2.4 & 40.6 & 47.3 & 43.5 \\
\hline October & 12.2 & 15.1 & 12.0 & 26.7 & 13.7 & 0.1 & 53.6 & 55.6 & 40.8 \\
\hline
\end{tabular}

*: Climate data provided from Nigde Meteorology Services General Directorate

The data was analyzed using standard technique of analysis of variance (ANOVA) and treatment means were separated by Least Significant Differences (LSD) at 5\% probability level by using SAS statistical software packages version 9.00 as described by Steel and Torrie (1980).

\section{RESULTS AND DISCUSSIONS}

\section{Yield and yield components}

The variance sources and their statistical significance were shown in Table 3 and 4 for the yield, yield components and tuber quality. Data of variance analysis in Table 3 showed that the effect of the $\mathrm{GA}_{3}$ applications on SPAD values were statistically significant at $1 \%$ probability level. The highest average leaf chlorophyll content was recorded in cultivar Agria (41.72) and the lowest average leaf chlorophyll value was recorded in cultivar Alegria (34.37) in both years (Table 5). The SPAD values of plants sprayed with $\mathrm{GA}_{3}$ were lower than that of control. Previously, the study of Hou et al. (2018) also observed that the SPAD values were decreased as the amount of $\mathrm{GA}_{3}$ increased. Similarly, Wang et al. (2018) reported that leaf chlorophyll content was significantly reduced after $\mathrm{GA}_{3}$ treatments. However, on the contrary Zainaldeen and Rasool (2018) found that the leaf chlorophyll content was increased with the increase of $\mathrm{GA}_{3}$ in potatoes. In addition, El-Hamady (2017) reported that the increase in the amount of $\mathrm{GA}_{3}$ enhanced the chlorophyll content in the leaves.

Plant height was significantly $(\mathrm{p}<0.01)$ affected by year, cultivar and $\mathrm{GA}_{3}$ (Table 3 ). Data recorded on growth parameters of potato revealed that $\mathrm{GA}_{3}$ increased the plant height of all cultivars i.e., Marabel, Alegria and Agria. The response to the $\mathrm{GA}_{3}$ varied according to the cultivars. The highest plant height value was measured at cv. Agria and also plant height increased due to increasing $\mathrm{GA}_{3}$ doses (Table 6). Therefore, the highest plant height value was obtained from the $100 \mathrm{mg} \mathrm{L}^{-1} \mathrm{GA}_{3}$ application. Plant height could be affected by several factors. It has been reported that the plant height was influenced by soil fertility, environmental factors, vegetation period (Ekin, 2009), and agricultural activities (Yildirim et al., 2019). The process of plant growth consists of two steps as cell division and cell elongation. The increase in plant height owing to the $\mathrm{GA}_{3}$ application might be due to $\mathrm{GA}_{3}$ effect on the elongation of internodes and shoot growth. Reza et al. (2015) recommended that the $\mathrm{GA}_{3}$ causes increase in cell number and cell size resulting on a significant effect on growth. Chindi and Tsegaw (2019) reported that $\mathrm{GA}_{3}$ applied on the foliage increased plant growth $(8 \%)$ as compared to the control, and it may be related to the effect of internodes and shoot growth. The present study is in the agreement with Alexopoulos et al. (2007) and Chindi and Tsegaw (2019) who reported similar results.

The means of the number of stem were presented in Table 3. Analysis of variance given in Table 3 showed that the $\mathrm{GA}_{3}$ application doses were not significant for number of stem. Cultivar $\times \mathrm{GA}_{3}$ application interaction on stem number plant $^{-1}$ was statistically significant at the $1 \%$ probability level in both years. According to the means given in Table 6, number of stem plant ${ }^{-1}$ Marabel cultivar was higher than that the other cultivars. Dormancy is an important factor limiting the number of stems in potato. Otroshy (2006) reported that longer stems were obtained with the application of $\mathrm{GA}_{3}$ in the Marfona potato cultivar, but the number of stems was reduced. During the flowering period, the $\mathrm{GA}_{3}$ application had no significant affect over the control. 
Table 3. Results of variance analysis of the growth and yield components in the experiment conducted in 2019 and 2020

\begin{tabular}{|c|c|c|c|c|c|c|}
\hline $\begin{array}{l}\text { Source of } \\
\text { Variation }\end{array}$ & df & $\begin{array}{c}\text { SPAD } \\
\text { (Chlorophyll } \\
\text { content) }\end{array}$ & $\begin{array}{c}\text { Plant } \\
\text { height } \\
(\mathrm{cm})\end{array}$ & $\begin{array}{l}\text { Number of } \\
\text { stem plant }^{-1}\end{array}$ & $\begin{array}{l}\text { Number of } \\
\text { tubers plant }{ }^{-1}\end{array}$ & $\begin{array}{c}\text { Tuber yield } \\
\text { plant }^{-1}(\mathrm{~g})\end{array}$ \\
\hline Year (Y) & 1 & 2.42 & $279.65 * *$ & 5.17 & 1.38 & $181.36 * *$ \\
\hline Cultivar (C) & 2 & $267.60 * *$ & $581.15^{* *}$ & $70.01 * *$ & $45.45^{* *}$ & $42.53 * *$ \\
\hline $\mathrm{GA}_{3} \operatorname{Doses}(\mathrm{G})$ & 2 & $49.71 * *$ & $50.20 * *$ & 0.82 & $127.86^{* *}$ & $28.86 * *$ \\
\hline $\mathrm{Y} \times \mathrm{C}$ & 2 & 0.41 & 3.12 & 1.37 & 0.76 & 0.68 \\
\hline$Y \times G$ & 3 & 0.87 & 0.11 & 0.07 & 0.24 & 0.07 \\
\hline $\mathrm{C} \times \mathrm{G}$ & 6 & 0.64 & 2.23 & $3.63 * *$ & 1.94 & 0.51 \\
\hline$Y \times C \times G$ & 6 & 0.04 & 0.08 & 0.21 & 0.19 & 0.22 \\
\hline $\mathrm{CV}(\%)$ & - & 3.13 & 4.48 & 6.53 & 8.94 & 6.18 \\
\hline
\end{tabular}

Table 4. Results of variance analysis of the yield and tuber quality in the experiment conducted in 2019 and 2020

\begin{tabular}{|c|c|c|c|c|c|c|c|}
\hline $\begin{array}{l}\text { Source of } \\
\text { Variation }\end{array}$ & df & $\begin{array}{c}\text { Marketable } \\
\text { tuber ratio } \\
(\%)\end{array}$ & $\begin{array}{c}\text { Unmarketable } \\
\text { tuber ratio } \\
(\%)\end{array}$ & $\begin{array}{c}\text { Total tuber } \\
\text { yield } \\
\left(\text { ton } \text { ha }^{-1}\right)\end{array}$ & $\begin{array}{c}\text { Dry matter } \\
\text { content } \\
(\%)\end{array}$ & $\begin{array}{l}\text { Specific } \\
\text { gravity } \\
\left(\mathrm{g} / \mathrm{cm}^{\mathbf{3}}\right)\end{array}$ & $\begin{array}{c}\text { Chips } \\
\text { Quality } \\
\text { (L) }\end{array}$ \\
\hline Year $(Y)$ & 1 & 1.32 & $13.21 * *$ & $90.04 * *$ & 0.10 & 0.01 & $19.15^{* *}$ \\
\hline Cultivar (C) & 2 & 0.96 & $9.78 * *$ & $11.67 * *$ & $12.23 * *$ & $11.44 * *$ & $12.67 * *$ \\
\hline $\mathrm{GA}_{3}$ Doses G) & 2 & $62.65 * *$ & $19.66 * *$ & $23.88 * *$ & $51.57 * *$ & $29.35 * *$ & $3.35^{*}$ \\
\hline $\mathrm{Y} \times \mathrm{C}$ & 2 & $5.82 * *$ & $9.81 * *$ & 0.84 & 0.14 & 0.17 & $11.77 * *$ \\
\hline$Y \times G$ & 3 & 0.42 & 1.56 & 0.10 & 0.03 & 0.29 & 0.39 \\
\hline $\mathrm{C} \times \mathrm{G}$ & 6 & 0.87 & 0.48 & 0.44 & 4.25 & 4.03 & 1.32 \\
\hline $\mathrm{Y} \times \mathrm{C} \times \mathrm{G}$ & 6 & 1.35 & 2.11 & 0.31 & 0.18 & 0.13 & 1.33 \\
\hline $\mathrm{CV}(\%)$ & - & 1.75 & 47.99 & 8.60 & 2.53 & 0.26 & 5.87 \\
\hline
\end{tabular}

Variation for the $\mathrm{GA}_{3}$ application for tuber number plant $^{-1}$ was statistically significant at $1 \%$ probability level (Table 3). When the means of over the two years are evaluated, the highest number of tubers plant ${ }^{-1}$ was obtained from Alegria (Table 5). The $\mathrm{GA}_{3}$ treatments resulted in significant increases in tuber number plant ${ }^{-1}$ as compared with control. The $100 \mathrm{mg} \mathrm{L}^{-1} \mathrm{GA}_{3}$ application was highly stimulatory in increasing the number of tubers plant $^{-1}$. Bandara et al. (1998) mentioned that when plants were applied once with GA during the early growth stage, the number of tubers plant ${ }^{-1}$ were increased, but this effect is critically dependent on the time of the $\mathrm{GA}_{3}$ application (Alexopoulos et al., 2007). Caldiz (1996) reported that foliar applied $\mathrm{GA}_{3}$ significantly increased tuber number plant ${ }^{-1}$ and the effect of $\mathrm{GA}_{3}$ application on tuber number was mainly due to an increase in the length and branching of the main stolon. The increase in tuber number might be due to the stimulated stolon production and increased photosynthetic activity. Otroshy (2006) determined that the highest and lowest amount of $\mathrm{GA}_{3}$ had a significant effect on tuber number, and El-Hamady (2017) determined that the application of $\mathrm{GA}_{3}$ to tubers before planting increased number of tubers plant ${ }^{-1}$.

Highly significant difference was observed among the $\mathrm{GA}_{3}$ treatments with regard to tuber yield plant ${ }^{-1}$ (Table $3)$. It has been determined that there was the significant (1\%) difference between years, cultivars and the $\mathrm{GA}_{3}$ applications for average tuber yield plant $^{-1}$. The highest tuber yield plant $^{-1}$ was obtained from the Alegria cultivar while the lowest was obtained from Marabel (Table 6). The tuber yield plant ${ }^{-1}$ increased when the $\mathrm{GA}_{3}$ doses were increased, and the mean of two years was $1101.0 \mathrm{~g}$ at the $0 \mathrm{mg} \mathrm{L} \mathrm{L}^{-1} \mathrm{GA}_{3}$ (Control) application but increased up to $1318.9 \mathrm{~g}$ at the $100 \mathrm{mg} \mathrm{L}^{-1} \mathrm{GA}_{3}$ application. The best effect of $\mathrm{GA}_{3}$ application on tuber yield plant ${ }^{-1}$ was at the concentration of $100 \mathrm{mg} \mathrm{L}^{-1} \mathrm{GA}_{3}$ applications followed by the $50 \mathrm{mg}$, and $25 \mathrm{mg}$ application respectively (Table 6). Previous studies have shown that the $\mathrm{GA}_{3}$ application increases tuber yield plant ${ }^{-1}$ and tuber yield (Barani et al., 2013; Dahshan et al., 2018). However, Mikitzel (1993) reported that the application of $\mathrm{GA}_{3}$ to seed tubers before planting did not affect tuber yield. Sharma et al. (1998) reported that the application of $\mathrm{GA}_{3}$ in potatoes delayed tuber formation and also reduced tuber yield. Chindi and Tsegaw (2019) found that 750 and 1000 ppm $\mathrm{GA}_{3}$ applications increased had tuber yield plant $^{-1}$ by approximately $26 \%$ and $45 \%$, respectively as compared to the control $(562.80 \mathrm{~g})$. In comparison other studies, supporting results were obtained in this study indicator the $\mathrm{GA}_{3}$ applications increased tuber yield plant ${ }^{-1}$.

The $\mathrm{GA}_{3}$ applications decreased on average marketable tuber rate as compared to control, and significant differences were also obtained for $\mathrm{GA}_{3}$ (Table 4). $\mathrm{GA}_{3}$ applications of $100 \mathrm{mg} \mathrm{L}^{-1}$ decreased marketable tuber ratio by $6,8 \%$ as compared to the control (Table 7). Karaat (2011) reported that increasing $\mathrm{GA}_{3}$ doses decreased the tuber size in potato tuber. Sharma et al. (1998) observed that foliar application of $\mathrm{GA}_{3}$ caused deformed tubers and some of tubers were sickle-shaped. Likewise, Jackson (1996) reported that the $\mathrm{GA}_{3}$ encouraged stolon growth and caused the tubers to be more elongated and elliptical than normal type. It has been 
demonstrated that spray application of $\mathrm{GA}_{3}$ to leaf during the growing period and seed tuber before planting promotes size distribution ratio among tubers from largest tuber to smallest tuber (Struik et al., 1989; Karaat, 2011).
In this study, the average marketable tuber yield decreased as compared to control with increase of $\mathrm{GA}_{3}$ doses similar to other studies (Karaat, 2011).

Table 5. Means of over two years for chlorophyll content SPAD, number of tuber plant ${ }^{-1}$, total tuber yield (ton/ha $\left.{ }^{-1}\right)$, dry matter content and specific gravity of three potato cultivars evaluated under different $\mathrm{GA}_{3}$ doses.

\begin{tabular}{|c|c|c|c|c|c|}
\hline Treatment & $\begin{array}{c}\text { SPAD } \\
\text { (Chlorophyll } \\
\text { content) }\end{array}$ & $\begin{array}{c}\text { Number of } \\
\text { tubers } \\
\text { plant }^{-1} \\
\end{array}$ & $\begin{array}{l}\text { Total tuber yield } \\
\quad\left(\text { ton } \text { ha }^{-1}\right)\end{array}$ & $\begin{array}{c}\text { Dry matter } \\
\text { content } \\
(\%)\end{array}$ & $\begin{array}{r}\text { Specific } \\
\text { gravity } \\
\left(\mathrm{g} / \mathrm{cm}^{3}\right)\end{array}$ \\
\hline \multicolumn{6}{|l|}{ Cultivar (C) } \\
\hline Agria & $41.72 \mathrm{a}$ & $10.50 \mathrm{~b}$ & $52.63 \mathrm{~b}$ & $19.08 \mathrm{~b}$ & $1.0740 \mathrm{~b}$ \\
\hline Alegria & $34.37 \mathrm{c}$ & $12.90 \mathrm{a}$ & $56.66 \mathrm{a}$ & $19.47 \mathrm{a}$ & $1.0769 \mathrm{a}$ \\
\hline Marabel & $35.77 \mathrm{~b}$ & $10.48 \mathrm{~b}$ & $50.36 \mathrm{~b}$ & $18.79 \mathrm{c}$ & $1.0731 \mathrm{~b}$ \\
\hline $\operatorname{LSD}_{(0.05)}$ & 0.67 & 0.58 & 26.57 & 0.28 & 0.0017 \\
\hline \multicolumn{6}{|c|}{$\mathrm{GA}_{3}$ Doses $(\mathrm{G})$} \\
\hline 0 & $39.31 \mathrm{a}$ & $8.28 \mathrm{~d}$ & $47.10 \mathrm{~d}$ & $19.99 \mathrm{a}$ & $1.0790 \mathrm{a}$ \\
\hline 25 & $38.31 \mathrm{~b}$ & $9.93 \mathrm{c}$ & $51.39 \mathrm{c}$ & $19.62 \mathrm{~b}$ & $1.0762 \mathrm{~b}$ \\
\hline 50 & $36.64 \mathrm{c}$ & $12.67 \mathrm{~b}$ & $54.85 \mathrm{~b}$ & $18.55 \mathrm{c}$ & $1.0728 \mathrm{c}$ \\
\hline 100 & $34.89 \mathrm{~d}$ & $14.28 \mathrm{a}$ & $59.54 \mathrm{a}$ & $18.29 \mathrm{c}$ & $1.0707 \mathrm{~d}$ \\
\hline $\operatorname{LSD}_{(0.05)}$ & 0.78 & 0.67 & 3.06 & 0.32 & 0.0019 \\
\hline
\end{tabular}

Tubers smaller than $25 \mathrm{~mm}$ in diameter, green, damaged and deformed were accepted as unmarketable tubers and they were used as animal food. But high rate of unmarketable tubers is not desirable in potato production. Unmarketable tuber content rate was significantly $(p<0.01)$ affected by year, cultivar, $\mathrm{GA}_{3}$ application and the year $x$ cultivar interaction (Table 4 ). When the data of the two years are evaluated, unmarketable tuber content rate decreased as $\mathrm{GA}_{3}$ dose was increased, and the unmarketable tuber content rate, which was $0.81 \%$ for control application, increased to $3.06 \%$ at the $100 \mathrm{mg} \mathrm{L}^{-1}$ $\mathrm{GA}_{3}$ application (Table 7). The $\mathrm{GA}_{3}$ application at the time of tuber initiation (50 days after planting) increased the yields in the smaller classes (smaller than $25 \mathrm{~mm}$ diameter), while reducing the yields of the marketable tuber. Struik et al. (1989) reported that the maximum effect was obtained when the GA was applied on the day of 40. Dahshan et al. (2018) found that the $\mathrm{GA}_{3}$ applications reduced the rate of unmarketable tuber. Karaat (2011) reported that $\mathrm{GA}_{3}$ applications have significantly increased average unmarketable tuber rate. Increasing $\mathrm{GA}_{3}$ doses increased the rate of unmarketable tubers while average unmarketable tuber rate was $7.9 \%$ non $\mathrm{GA}_{3}$ application, and it was $56.3 \%$ in the $150 \mathrm{mg} \mathrm{L}^{-1}$ $\mathrm{GA}_{3}$ application.

The total tuber yield of potato was significantly affected by year, cultivar and $\mathrm{GA}_{3}$ applications (Table 4). Tuber yield significantly varied among cultivars and $\mathrm{GA}_{3}$ application. The highest total tuber yield was obtained from Alegria with 62.78 ton $\mathrm{ha}^{-1}$ in 2019. Also effect of $\mathrm{GA}_{3}$ applications were significant on tuber yield. The highest tuber yield was obtained from the $100 \mathrm{mg} \mathrm{L}^{-1}$ dose 65.14 ton ha $\mathrm{ha}^{-1}$ in 2019 (Table 5). Generally, in our study, tuber yields in 2019 were higher than those of the 2020 . The main reason for this difference was due to different environmental factors of growing seasons. In potato, high temperatures promote vegetative growth, but reduce tuber growth. Menzel (1984) reported that the reduction in tuber growth by the GA was accompanied by a promotion of haulm weight and high temperatures strongly reduced tuber number and harvest index. In the 2019 growing season, mean temperatures $\left({ }^{\circ} \mathrm{C}\right)$ were higher than that the other experiment year in our study (Table 2). Therefore, total tuber yield reduced due to the high temperature especially during tuber formation stage in 2020. Total tuber yield was affected significantly by the $\mathrm{GA}_{3}$. In 2019 and 2020 years, the $100 \mathrm{mg} \mathrm{L}^{-1} \mathrm{GA}_{3}$ application caused an increase in tuber yield as compared to the control and increase in total tuber yield was approximately $25 \%$ and $28 \%$ in 2019 and 2020, respectively. Sillu et al. (2012) informed that tuber yield in the $\mathrm{GA}_{3}$ application to seed tuber during planting was higher than that the foliar application of the $\mathrm{GA}_{3}$ and foliar application of plant growth regulator with better penetration into leaves increased the leaf chlorophyll content increasing in the photosynthetic rate and in turn increased the growth of plants this resulting in higher yield attributes and yield than that of the seed treatment method. Studies conducted by Njoqu et al. (2015) revealed that the application of $\mathrm{GA}_{3}$ during planting on seed tubers accelerated shoot formation and emergence resulting in higher tuber yield. Dahshan et al. (2018) found that the $\mathrm{GA}_{3}$ applications increased total tuber yield as compared to the control. In our study, all cultivars responded positively to increasing $\mathrm{GA}_{3}$ doses so increased total tuber yield resulted in.

\section{Tuber quality characteristics}

Potato quality traits including dry matter content, specific gravity and starch content are important in food industry and directly affect the quality and processing quality of the final product. Variances given in Table 4 showed that the effect of $\mathrm{GA}_{3}$ application on dry matter content of tuber was statistically significant. The highest dry matter content was obtained from Alegria as $19.47 \%$. 
It was observed that tuber dry matter content was decreased with increasing $\mathrm{GA}_{3}$ doses in our study and there was a negative relationship between the $\mathrm{GA}_{3}$ doses and dry matter content. In 2019 and 2020 years, it was observed that mean tuber dry matter content was $19.99 \%$ in control, while it was $18.29 \%$ in the $100 \mathrm{mg} \mathrm{L}^{-1} \mathrm{GA}_{3}$ application (Table 5). Javanmardi and Rasuli (2017) reported that the tuber dry matter rate decreased due to an increase in the $\mathrm{GA}_{3}$ concentration. Alexopoulos et al. (2007) explained that the $\mathrm{GA}_{3}$ caused a significant reduction in the dry matter content of tubers, while the rate of respiration (measured 10 day after harvest) was significantly higher. The reduction in tuber dry matter content following the $\mathrm{GA}_{3}$ application could be due to a decline in starch content which was a result of sucrose interception by the shoots, and restricted sucrose supply to the tubers (Sharma et al., 1998).

Significant differences were found with regard to specific gravity among different $\mathrm{GA}_{3}$ doses (Table 4). Increasing $\mathrm{GA}_{3}$ doses caused a decrease in tuber specific gravity and it varied between 1.0707 and 1.0790 in all treatments (Table 5). It was defined that if the tuber specific gravity values are less than 1.077 was Low, if it is between 1.077 and 1.086 was Medium and it was defined as high if it is more than 1.086. The specific gravity of potatoes was very different and ranged from 1.050 to 1.106. Specific gravity values of potatoes determined the intended use of tubers. Chindi and Tsegaw (2019) reported that high rates of the $\mathrm{GA}_{3}$ application in potatoes had higher specific gravity and dry matter rate than those of non-application tubers. Therefore, there was a significant and positive relationship between specific gravity and dry matter content. Likewise, Degebasta (2010) explained that the haulm application of $\mathrm{GA}_{3}$ increased specific gravity by about $2 \%$ and dipping seed tubers in $50 \mathrm{ppm}$ of $\mathrm{GA}_{3}$ solution increased the tuber specific gravity of the next generation by $1.3 \%$ as compared to the control application. On the contrary, the $\mathrm{GA}_{3}$ application decreased tuber specific gravity in potatoes in both years in this study Alexopoulos et al. (2007) found that application of the $\mathrm{GA}_{3}$ at a more mature stage of plant growth, i.e. at 60 days after planting had no effect on tuber dry matter content, when the tuberization and presumably starch synthesis was virtually complete.

Table 6. Means of the plant height, number of stem plant ${ }^{-1}$ and tuber yield plant ${ }^{-1}$

\begin{tabular}{|c|c|c|c|c|c|c|c|c|c|}
\hline \multirow{2}{*}{ Treatment } & \multicolumn{3}{|c|}{ Plant height $(\mathrm{cm})$} & \multicolumn{3}{|c|}{ Number of stem plant ${ }^{-1}$} & \multicolumn{3}{|c|}{ Tuber yield plant $^{-1}(\mathrm{~g})$} \\
\hline & 2019 & 2020 & Mean & 2019 & 2020 & Mean & 2019 & 2020 & Mean \\
\hline \multicolumn{10}{|l|}{ Cultivar (C) } \\
\hline Agria & $91.48 \mathrm{a}$ & $80.98 \mathrm{a}$ & $86.23 \mathrm{a}$ & $6.11 \mathrm{a}$ & $5.71 \mathrm{a}$ & $5.91 \mathrm{a}$ & $1290.3 b$ & $1083.0 \mathrm{~b}$ & $1186.6 \mathrm{~b}$ \\
\hline Alegria & $80.00 \mathrm{~b}$ & $64.98 b$ & $72.51 \mathrm{~b}$ & $4.95 b$ & $4.86 \mathrm{~b}$ & $4.90 \mathrm{~b}$ & $1435.5 \mathrm{a}$ & $1185.1 \mathrm{a}$ & $1310.3 \mathrm{a}$ \\
\hline Marabel & $60.98 \mathrm{c}$ & $48.76 c$ & $54.87 \mathrm{c}$ & $6.11 \mathrm{a}$ & $6.00 \mathrm{c}$ & $6.06 \mathrm{a}$ & $1239.9 b$ & $998.6 b$ & $1114.2 \mathrm{c}$ \\
\hline $\operatorname{LSD}_{(0.05)}$ & 5.36 & 1.09 & 1.85 & 0.45 & 0.13 & 0.21 & 98.37 & 59.9 & 43.2 \\
\hline \multicolumn{10}{|l|}{$\mathrm{GA}_{3}$ Doses $(\mathrm{G})$} \\
\hline 0 & $71.12 b$ & $59.16 \mathrm{~d}$ & $65.14 \mathrm{~d}$ & 5.62 & 5.48 & 5.55 & $1222.8 \mathrm{c}$ & $979.2 \mathrm{c}$ & $1101.0 \mathrm{~d}$ \\
\hline 25 & $74.98 b$ & $62.52 \mathrm{c}$ & $68.75 c$ & 5.67 & 5.47 & 5.57 & $1282.7 b c$ & $1037.9 \mathrm{c}$ & $1160.3 \mathrm{c}$ \\
\hline 50 & $80.13 a$ & $67.22 \mathrm{~b}$ & $73.67 b$ & 5.77 & 5.53 & 5.65 & $1350.5 b$ & $1118.9 b$ & $1234.7 b$ \\
\hline 100 & $83.76 a$ & $70.73 a$ & $77.25 \mathrm{a}$ & 5.83 & 5.62 & 5.72 & $1431.6 a$ & $1206.2 \mathrm{a}$ & $1318.9 a$ \\
\hline $\operatorname{LSD}_{(0.05)}$ & 13.40 & 1.26 & 2.14 & 0.76 & 0.15 & 0.24 & 119.1 & 69.2 & 49.9 \\
\hline
\end{tabular}

Table 7. Means of the marketable and unmarketable tuber ratio (\%) and chips quality (L)

\begin{tabular}{|c|c|c|c|c|c|c|c|c|c|}
\hline \multirow{2}{*}{ Treatment } & \multicolumn{3}{|c|}{ Marketable tuber ratio (\%) } & \multicolumn{3}{|c|}{ Unmarketable tuber ratio $(\%)$} & \multicolumn{3}{|c|}{ Chips quality (L) } \\
\hline & 2019 & 2020 & Mean & 2019 & 2020 & Mean & 2019 & 2020 & Mean \\
\hline \multicolumn{10}{|l|}{ Cultivar (C) } \\
\hline Agria & 94.00 & $94.20 \mathrm{a}$ & 94.10 & 1.59 & $1.69 \mathrm{~b}$ & $1.64 \mathrm{~b}$ & $62.53 \mathrm{a}$ & $60.54 b$ & $61.54 \mathrm{a}$ \\
\hline Alegria & 93.56 & $94.31 \mathrm{a}$ & 93.94 & 1.71 & $1.85 b$ & $1.77 \mathrm{~b}$ & $58.79 b$ & $64.42 \mathrm{a}$ & $61.60 \mathrm{a}$ \\
\hline Marabel & 94.61 & $92.33 b$ & 93.47 & 1.64 & $3.97 \mathrm{a}$ & $2.80 \mathrm{a}$ & $53.48 \mathrm{c}$ & $60.77 b$ & $57.13 b$ \\
\hline $\operatorname{LSD}_{(0.05)}$ & 1.63 & 1.05 & 0.95 & 0.97 & 0.65 & 0.57 & 2.61 & 3.39 & 2.05 \\
\hline \multicolumn{10}{|l|}{$\mathrm{GA}_{3}$ Doses $(\mathrm{G})$} \\
\hline 0 & $97.43 \mathrm{a}$ & $97.37 \mathrm{c}$ & $97.40 \mathrm{a}$ & $0.73 c$ & $0.89 \mathrm{c}$ & $0.81 \mathrm{c}$ & 60.27 & 63.71 & $61.99 \mathrm{a}$ \\
\hline 25 & $95.57 \mathrm{a}$ & $95.07 \mathrm{~b}$ & $95.31 \mathrm{~b}$ & $1.37 \mathrm{bc}$ & $1.93 \mathrm{~b}$ & $1.65 \mathrm{~b}$ & 58.96 & 61.27 & $60.11 \mathrm{ab}$ \\
\hline 50 & $92.48 b$ & $91.34 \mathrm{a}$ & $91.91 \mathrm{c}$ & $2.11 \mathrm{ab}$ & $3.44 \mathrm{a}$ & $2.78 \mathrm{a}$ & 57.62 & 62.40 & $60.01 \mathrm{ab}$ \\
\hline 100 & $90.75 b$ & $90.67 \mathrm{a}$ & $90.71 d$ & $2.38 \mathrm{a}$ & $3.74 \mathrm{a}$ & $3.06 \mathrm{a}$ & 56.27 & 60.27 & $58.25 b$ \\
\hline $\operatorname{LSD}_{(0.05)}$ & 1.88 & 1.21 & 1.10 & 0.93 & 0.75 & 0.66 & 4.62 & 3.91 & 2.36 \\
\hline
\end{tabular}

Variation for chips quality (L) of potato was significantly for year, cultivar, $\mathrm{GA}_{3}$ application and year $\mathrm{x}$ cultivar interaction. The $\mathrm{L}$ value was changed between
56.27 and 63.71 in two years (Table 7). The highest L value was obtained from Agria in 2019 and Alegria in 2020. The highest values for chips quality were obtained 
from the control with non $\mathrm{GA}_{3}$ application. Therefore, increasing the $\mathrm{GA}_{3}$ doses decreased the chips quality. Burton (1989) stated that the color of chips in potatoes is a characteristic of cultivar, but changeable depending on the cultural practices during the growing period, the maturity of the potato tubers and the storage conditions. The amount of reducing sugar in the tuber varied according to the applied cultural practices fertilization (Yildirim, 2019), growth conditions, storage, stress conditions during growth, cultivar, frying temperature and slice thickness of the potatoes to be fried (Burton, 1989). In addition, Javanmardi and Rasuli (2017) explained that increased level of sugar reduction with the application of $\mathrm{GA}_{3} \cdot \mathrm{GA}_{3}$ may reduce starch-synthesizing capacity by reducing ADP-Glc-pyro phosphorylase activity by the decrease in starch synthesis (Mares et al., 1981). In this study, considering changes of the dry matter contents of the tuber with in $\mathrm{GA}_{3}$ applications, the chips quality would vary with the $\mathrm{GA}_{3}$ applications.

\section{CONCLUSION}

Foliar application of $\mathrm{GA}_{3}$ affects not only plant growth, tuber yield and yield component, but also the tuber quality characters such as dry matter content, specific gravity and chips quality of the tubers. Three potato cultivars tested had significant differences for growth, yield, yield parameters and some quality traits. Number of tuber plant ${ }^{-1}$, tuber yield plant $^{-1}$, total tuber yield, dry matter content, specific gravity and chips quality of Alegria cultivar that is mid-early were enhanced by $\mathrm{GA}_{3}$ treatments and gave the highest values compared to other cultivars. Increasing gibberellic acid doses reduced the chips quality, dry matter content and specific gravity of potato tuber. In contrast, total tuber yield increased with increasing $\mathrm{GA}_{3}$ doses from $0 \mathrm{mg} / \mathrm{L}^{-1}$ to 100 $\mathrm{mg} / \mathrm{L}^{-1}$, besides, unmarketable tuber ratio has also increased. Storage of potatoes is an important stage of the potato production and cultural practices during the growing period affect the storage period. Therefore, it could be beneficial to conduct further research on the post-harvest storage life of tubers treated with the $\mathrm{GA}_{3}$ application.

\section{LITERATURE CITED}

Abdala, G., G. Castro, O. Miersch and D. Pearce. 2000. Changes in jasmonate and gibberellin levels during development of potato plants (Solanum tuberosum L). Plant Growth Regulators 36(2): 121-126.

Alexopoulos, A.A., G. Aivalakis, K.A. Akoumianakis and H.C. Passam. 2007. Effect of foliar applications of gibberellic acid or daminozide on plant growth, tuberisation, and carbohydrate accumulation in tubers grown from true potato seed. J. Hort. Sci. Biotechnol. 82: 535-540.

Algul, B.E., F.E. Tekintas and G.G. Dalkilic. 2016. The use of plant growth regulators and applications to increase the biosynthesis of internal hormones. Adnan Menderes Uni. Journal of Agriculture Faculty, 13(2): 87-95 (in Turkish).

Bandara, M.S., K.K. Tanino and D.R. Waterer. 1998. Effect of pot size and timing of plant growth regulator treatments on growth and tuber yield in greenhouse-grown Norland and Russet Burbank potatoes. J. Plant Growth Regul. 17: 75-79.
Barani, M, N. Akbari and H. Ahmadi. 2013. The effect of gibberellic acid $\left(\mathrm{GA}_{3}\right)$ on the size and sprouting of potato tubers (Solanum tuberosum L.). African Journal of Agriculture Research 8(29): 3899-3903.

Burton, W.G. 1989. The potato. Third edition, John Wiley and Sons, Inc New York, NY. P. 742.

Caldiz, D.O. 1996. Seed potato (Solanum tuberosum L.) yield and tuber number increase after foliar applications of cytokinins and gibberellic acid under field and glasshouse conditions. Plant Growth Regul. 20: 185-88.

Caliskan, M.E., H. Onaran and H. Arioglu. 2010. Overview of the Turkish potato sector: Challenges, achievements and expectations. Potato Research 53:255-266.

Chindi, A. and T. Tsegaw. 2019. Effect of gibberellic acid on growth, yield and quality of potato (Solanum tuberosum L.) in central highlands of Ethiopia. Journal Horticulture Sci. For. 1(2): 1-10.

Dahshan, A.M.A., H.E.M. Zaki, Y.M.M. Moustafa, Y.T. AbdelMageed and M.A.M. Hassan. 2018. Effect of some growth regulators and natural extracts on yield and quality of potato. Minia Journal of Agriculture Research and Development 38(2): 271-295.

Degebasta, A.C. 2010. Effect of Gibberellic acid on tuber dormancy breaking, subsequent growth, yield quality of potato (Solanum tuberosum L.). MSc Thesis, School of Graduate Studies Department of Plant Science, Haramaya University, 1-78.

Ekin, Z. 2009. Determination of yield and quality properties of some potato (Solanum tuberosum L.) varieties in Ahlat ecological conditions. Harran University Journal of Agriculture Faculty 13(3): 1-10 (in Turkish).

El-Hamady, M.M. 2017. Growth and yield of potato Solanum tuberosum $\mathrm{L}$. as influenced by soaking in $\mathrm{GA}_{3}$ and potassium fertilizer rates. Canadian Journal of Agriculture and Crops 2(1): 50-59.

Hou, K., J.W. Chen, J.Y. Li, H. Shen, L. Chen and W. Wu. 2018. Effect of gibberellic acid and chlormequat chloride on growth, coumarin content and root yield of Angelica dahurica var. formosana. J. Agr. Sci. Tech. 15: 1415-1423.

Jackson, S.D. and S. Prat. 1996. Control of tuberization in potato by gibberellins and phytochrome B. Physiol. Plant. 98:407412.

Javanmardi, J. and F. Rasuli. 2017. Potato yield and tuber quality as affected by gibberellic acid and zinc sulphate. Iran Agricultural Research 36(2): 7-12.

Karaat, F.E. 2011. Effects of different growth regulators applications on plant growth and tuber yield and quality in early and main product potato growing. MSc Thesis. Hatay Mustafa Kemal University, Graduate School of Natural and Applied Sciences, p: 90 (in Turkish)

Kolomiets, M.V., D.J. Hannapel, H. Chen, M. Tymeson and R.J. Gladon. 2001. Lipoxygenase is involved in the control of potato tuber development. The Plant Cell Online. 13(3): 613626.

Kumlay, A.M. and T. Eryigit. 2011. Substances Regulating Growth and Development in Plants: Plant Hormones. Igdir University Journal of Science Institute 1(2):47-56.

Mares, D.J., H. Marscfaner and A. Krauss. 1981. Effect of gibberellic acid on growth and carbohydrate metabolism of developing tubers of potato (Solanum tuberosum). Physiologia Plantarum 52(2): 267-274.

Menzel, C.M. 1984. Potato as a potential crop for the lowland tropics. Tropical Agriculture 61(3): 162-166.

Mikitzel, L.J. 1993. Influencing seed tuber yield of Ranger Russet and Shepody potatoes with Gibberellic acid. American Potato Journal 70: 667-676. 
Njoqu, M.K., G.K. Gathungu and P.M. Daniel. 2015. Comparative effects of foliar application of gibberellic acid and benzylaminopurine on seed potato tuber sprouting and yield of resultant plants. American J. of Agriculture and Forestry 3(5): 192-201.

Otroshy, M. 2006. Utilization of tissue culture techniques in a seed potato tuber production scheme. $\mathrm{PhD}$ Thesis, Wageningen University. p: 1-264.

Puzina, T.I. 2004. Effect of zinc sulfate and boric acid on the hormonal status of potato plants in relation to tuberization. Russian Journal of Plant Physiology 51(2): 209-215.

Reza, M., M. Islam, A. Hoque, R.K. Sikder, H. Mehraj and A.F.M. Jamal Uddin. 2015. Influence of Different GA Concentrations on Growth and Yield of Broccoli. AmericanEurasian Journal of Scientific Research 10 (5): 332-335.

Sarkar, D. 2008. The signal transduction pathways controlling in planta tuberization in potato: an emerging synthesis. Plant Cell Reports 27(1): 1-8.

Sharma, N., N. Kaur and A.K. Gupta. 1998. Effects of gibberellic acid and chlorocholine chloride on tuberization and growth of potato (Solanum tuberosum L.). J. Food Sci. Agric. 78: 466-470.

Sillu, M., N.M. Patel, H.S. Bhadoria, and V.R. Wankhade. 2012. Effect of plant growth regulators and methods of application on growth and yield of potato (Solanum tuberosum L.) cv.
KUFRI BADSHAH. Advance Research Journal of Crop Improvement 3(2): 144-147.

Steel, R.G.D. and J.H. Torrie. 1980. Principles and procedures of statistics. 2nd ed. McGraw Hill, New York.

Struik, P.C., G. Kramer and N.P. Smit. 1989. Effects of soil applications of gibberellic acid on the yield and quality of tubers of Solanum tuberosum L. cv. Bintje. Potato Research 32(2): 203-209.

Vreugdenhil, D. and H. Helder. 1992. Hormonal and metabolic control of tuber formation. In: CM. Karssen L.C. van Loon and D. Vreugdenhil (eds.), Progress in Plant Growth Regulation. The Netherlands, Kluwer Academic Publishers.

Wang, C. C., X.Y. Wang, K.C. Wang, J.J. Hu, M.X. Tang, W. He and P. Vander Zaag. 2018. Manipulating aeroponically grown potatoes with gibberellins and calcium nitrate. American Journal of Potato Research 95(4): 351-361.

Yildirim, M. 2019. The Effects of Animal and Chemical Manure Applications on Plant Growth Yield and Quality in Potato (Solanum tuberosum L.)", MSc Thesis, Nigde Omer Halisdemir University. Graduate School of Natural and Applied Sciences, Nigde (in Turkish).

Zainaldeen, M.A. and I.J. Abdul Rasool. 2018. Effect of folair application of gibberellin and nutrients on growth and yield of potato var. "Burren". Iraqi Journal of Agricultural Sciences 49(2): 168-176. 